\title{
PENGEMBANGAN HOME INDUSTRY BERBASIS MINYAK TUMBUHAN ATSIRI DI DESA GENGGELANG, KECAMATAN GANGGA, KABUPATEN LOMBOK UTARA
}

\author{
Surya Hadi ${ }^{1 *}$, I Made Sudarma ${ }^{1}$, Maria Ulfa ${ }^{1}$, Emmy Yuanita ${ }^{1}$, Ni Komang Tri Dharmayani ${ }^{1}$ \\ ${ }^{1}$ Program Studi Kimia Fakultas Matematika dan IImu Pengetahuan Alam \\ Universitas Mataram \\ *Korespondensi: suryahadi@unram.ac.id
}

Diterima 4 November 2020 / Disetujui 5 Desember 2020

\begin{abstract}
ABSTRAK
Lombok Utara merupakan salah satu kabupaten di Provinsi Nusa Tenggara Barat dengan persentase penduduk miskin tertinggi mencapai 28,83\%. Kejadian gempa bumi yang berpusat di Kabupaten Lombok Utara (KLU) Tahun 2018 berdampak nyata pada penurunan perekonomian masyarakat. Oleh karena itu, diperlukan upaya untuk memulihkan dan meningkatkan perekonomian masyarakat diantaranya melalui pembukaan kesempatan kerja atau berusaha. Salah satu cara yang dapat dilakukan adalah melalui pemanfaatan sumber daya alam lokal yang tersedia menjadi produk bernilai ekonomi tinggi. Salah satu jenis sumber daya alam yang banyak tersedia di Kabupaten Lombok Utara, khususnya Desa Genggelang, Kecamatan Gangga yang menjadi pilihan lokasi kegiatan pengabdian masyarakat ini adalah tumbuhan penghasil minyak atsiri seperti kayu putih dan cengkeh. Pemanfaatan tumbuhan-tumbuhan tersebut sudah sangat dikenal luas sebagai sumber utama minyak atsiri baik sebagai minyak wangi maupun pemanfatan lainnya dalam bidang kesehatan. Kegiatan pengabdian masyarakat ini diarahkan untuk membina masyarakat desa dalam mengisolasi minyak atsiri dengan cara pemberian pemaparan mengenai teknik destilasi uap dan membuat produk kimia berbasis minyak kayu putih dan limbah daunnya seperti sabun, lotion dan lulur. Sehingga, dengan keterampilan ini diharapkan dapat menciptakan peluang usaha keluarga berbentuk industry rumah tangga yang mampu meningkatkan kesejahteraan masyarakat.
\end{abstract}

Kata kunci: Lombok Utara, pelatihan, minyak atsiri, home industry

\begin{abstract}
North Lombok is one of the districts in West Nusa Tenggara Province with the highest percentage of poor people reaching $28.83 \%$. The earthquake that was centered in North Lombok Regency (KLU) in 2018 also had a real impact on the decline in the community's economy. Therefore, efforts are needed to restore and improve the community's economy by opening job opportunities or doing business. One way that this can be done is through the use of available local natural resources into products of high economic value. One type of natural resource that is widely available in North Lombok Regency, especially Genggelang Village, Gangga District, which is the location of choice for community service activities is essential oil-producing plants such as eucalyptus and clove. The use of these plants is well
\end{abstract}


known as the main source of essential oils, both as perfume and other uses in the health sector. This community service activity is directed at fostering village communities in isolating essential oils by providing exposure to steam distillation techniques and making eucalyptus oil-based chemical products and its leaf waste such as soap, lotion and scrubs. So, with these skills it is hoped that it can create family business opportunities in the form of a home industry that can improve the welfare of the community.

Keywords: Northern Lombok, workshop, essential oil, home industry

\section{PENDAHULUAN}

Lombok Utara merupakan salah satu kabupaten di Provinsi Nusa Tenggara Barat dengan persentase penduduk miskin tertinggi mencapai 28,83\% (BPS, 2019). Kemiskinan ini mempengaruhi banyak sisi kehidupan masyarakat, terutama tingkat kesejahteraan yang terlihat menurun. Fenomena kemiskinan umumnya dikaitkan dengan kekurangan pendapatan untuk memenuhi kebutuhan-kebutuhan dasar, dan apa yang terjadi pada kemiskinan bergantung pada apa yang terjadi pada distribusi pendapatan dan konsumsi (Deaton, 2003).

Kejadian gempa bumi yang berpusat di Kabupaten Lombok Utara (KLU) tahun 2018 juga berdampak nyata pada penurunan perekonomian masyarakat. Berbagai permasalahan kemiskinan di Lombok Utara pasca gempa menjadi semakin kompleks dan membutuhkan penyelesaian segera. Salah satu upaya percepatan yang telah dilakukan oleh Pemerintah NTB untuk memulihkan perekonomian masyarakat pasca gempa adalah melalui pemanfaatan sumber daya alam, sebagai salah satu contoh, dengan mulai dihadirkannya industri minyak atsiri di Kabupaten Lombok Utara, diantaranya minyak atsiri dari tumbuhan cengkeh (clove oil), tumbuhan kayu putih (cajuput oil) dan tanaman serai wangi (citronela oil) (https://ppid.birohumasprotokol.ntbprov. go.id, 2019).

Pada dasarnya, daerah Lombok Utara ini khususnya di desa tujuan lokasi kegiatan pengabdian yakni Desa Genggelang, Kecamatan Gangga merupakan wilayah yang kaya akan sumber daya alam. Kekayaan sumber daya alam perlu diberdayakan untuk dapat meningkatkan kesejahteraan penduduk. Salah satu komoditas sumber daya alam yang dianggap mempunyai nilai ekonomi tinggi, memiliki banyak manfaat serta mudah diusahakan adalah tumbuhan ataupun tanaman penghasil minyak atsiri (essential oil), antara lain sereh wangi, akar wangi, nilam, cengkeh, kayu putih dan pala (Tanasale, 2012). Minyak atsiri dikenal dengan nama minyak eteris atau minyak terbang merupakan bahan yang bersifat mudah menguap (volatile), mempunyai rasa getir, dan bau mirip tanaman asalnya yang diambil dari bagianbagian tanaman seperti daun, buah, biji, bunga, akar, rimpang, kulit kayu, bahkan seluruh bagian tanaman. Minyak atsiri selain dihasilkan oleh tanaman, dapat juga sebagai bentuk dari hasil degradasi oleh enzim atau dibuat secara sintetis (Tirta et al, 2017).

Di sisi lain, permasalahan yang dihadapi masyarakat adalah keterampilan untuk memisahkan minyak atsiri dari bahan bakunya belum banyak diketahui karena keterbatasan pengetahuan, pengalaman dan keahlian. Oleh karena itu, dalam kegiatan pengabdian masyarakat ini dilakukan edukasi dan pelatihan tentang bagaimana memperoleh minyak atsiri dari berbagai komoditas tumbuhan atau tanaman atsiri yang terdapat di Desa Genggelang. Diharapkan, kegiatan 
pengabdian ini akan menjadi awal hadirnya industri rumah tangga (home industry) berbasis minyak atsiri. Selain keterampilan dalam mengisolasi minyak atsiri sebagai produk utama yang dapat dikomersilkan, keterampilan pembuatan produk turunan seperti lotion dan lulur penyegar dari limbah hasil home industry telah diberikan.

Dengan dibuatnya produk-produk oleh masyarakat sebagai kegiatan usaha rumah tangga (home industry), diharapkan kegiatan ini dapat membuka lapangan pekerjaan baru dan mandiri bagi masyarakat sehingga dapat meningkatkan pendapatan masyarakat. Upaya ini dilakukan sebagai langkah konkrit dalam mendukung pemerintah dan masyarakat untuk mengentaskan kemiskinan di Provinsi NTB, terutama memulihkan perekonomian masyarakat di Kabupaten Lombok Utara, khususnya di Desa Genggelang, Kecamatan Gangga.

Sesuai dengan kondisi lapangan dan kebutuhan masyarakat di lokasi pengabdian tujuan yang akan dicapai adalah diatasi, mengembangkaan home industry berbasis minyak tumbuhan atsiri sebagai usaha membuka peluang pekerjaan baru dan mandiri bagi masyarakat.

\section{METODE PELAKSANAAN}

Dalam kegiatan pengabdian masyarakat ini akan dilakukan pelatihan dan pemberian bantuan teknologi kepada masyarakat berupa teknologi sederhana destilasi uap untuk penyulingan minyak atsiri dari tumbuhan ataupun tanaman sumber minyak atsiri, serta transfer pengetahuan tentang cara pembuatan lotion dan lulur penyegar menggunakan residu daun tumbuhan atsiri limbah penyulingan. Adapun tahapan-tahapan yang dilakukan dalam melaksanakan kegiatan pengabdian ini meliputi:

\section{Persiapan lokasi pengabdian masyarakat}

Kegiatan pengabdian akan dilaksanakan di Desa Genggelang, Kecamatan Gangga, Kabupaten Lombok Utara. Pada tahap persiapan ini dilakukan kerjasama dengan kepala desa dengan meminta surat kesediaan untuk bekerjasama sesuai dengan tujuan kegiatan.

\section{Penyiapan paket teknologi penyulingan minyak atsiri dan formulasi produk}

Teknologi penyulingan yang digunakan adalah menggunakan destilasi uap. Pada tahap ini dilakukan optimasi peralatan destilasi uap melalui penyesuaian terhadap bahan baku lokal sumber minyak atsiri dari Desa Genggelang. Teknologi produksi formulasi produk mengacu pada hasil penelitian oleh Peneliti Kimia Bahan Alam, Fakultas MIPA Universitas Mataram.

\section{Penyiapan masyarakat target}

Adapun masyarakat target dari kegiatan pengabdian ini adalah masyarakat di Desa Genggelang. Kelompok masyarakat home industry ini diintegrasikan dengan Badan Usaha Milik Desa (Bumdes). Dalam kegiatan ini masyarakat dibagi menjadi dua kelompok binaan, kelompok penyuling minyak atsiri dan kelompok pembuat produk turunan minyak atsiri. Masing-masing kelompok terdiri atas 10 (sepuluh) orang yang mewakili keluarga.

\section{Pelatihan teknologi penyulingan minyak atsiri kepada masyarakat}

Pelatihan penyulingan minyak atsiri akan dilakukan di aula kantor Desa Genggelang dengan peserta yang terdiri atas 2 kelompok masyarakat yang telah bersedia untuk mengembangkan industri 
rumah tangga berbasis minyak atsiri. Pelatihan dilakukan dengan menggunakan metode ceramah dan demonstrasi. Untuk merealisasikan rencana pengembangan home industry berbasis minyak atsiri ini, akan dilakukan kerja sama dengan instansi terkait baik pada tingkat kabupaten maupun tingkat provinsi.

\section{Pelatihan teknologi formulasi produk}

Masyarakat yang menjadi target pengabdian diberikan pengetahuan dan keterampilan tentang cara membuat produk turunan dari minyak atsiri seperti lotion dan lulur penyegar. Seperti halnya pelatihan penyulingan minyak atsiri, pelatihan teknologi formulasi produk juga dilakukan dengan cara ceramah dan demonstrasi.

\section{Evaluasi kegiatan dan pendampingan}

Setelah rangkaian pelatihan telah dilakukan, kemudian dilaksanakan evaluasi dan pendampingan kepada masyarakat secara berkelanjutan agar lebih terampil dan kompeten terhadap pemanfaatan sumber daya lokal yang efisien serta tepat guna. Evaluasi dan pendampingan ini diarahkan untuk penyempurnaan proses produksi dan bantuan pemasaran.

Kegiatan ini direncanakan akan terus dibina dengan mengintegrasikan-nya ke dalam kegiatan yang dilakukan oleh Lembaga Penelitian dan Pengabdian Pada Masyarakat Universitas Mataram, dan organisasi pelaksana daerah yang berkompeten.

\section{HASIL DAN PEMBAHASAN}

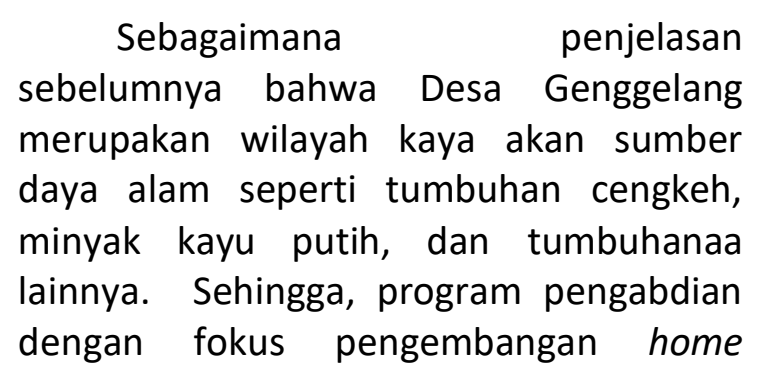

industry berbasis minyak tumbuhan atsiri akan berdampak secara nyata terhadap perekonomian keluarga dan diharapkan dapat menjadi model usaha masayarakat mandiri.

Pada kegiatan kali ini, seperti yang telah diuraikan sebelumnya, dilakukan pelatihan dalam dua tahap pelatihan, 1) teknik penyulingan minyak atsiri yang berasal dari daun tumbuhan kayu putih dan 2) pemanfaatan minyak atsiri dan limbah daun menjadi sabun, lotion dan lulur.

Adapun proses penyulingan minyak kayu putih digunakan alat destilasi uap seperti yang ditunjukkan Gambar1. Teknik pemisahan minyak atsiri dengan teknik ini didasarkan pada pemanfaatan uap air panas $\left(90-95^{\circ} \mathrm{C}\right)$ yang dilewatkan pada daun kayu putih yang membawa minya atsiri terpisah dan kemudiann cara dilewatkan dalam pendingin (kondensor). Air dan minyak atsiri ditampung dalam gelas ukur dimana pada glas ini, keduanya terpisah karena memiliki berat jenis berbeda. Kondensor bekerja dengan aliran air dingin yang dibuat mengalami sirkulasi di sekitar aliran air dan mengubah uap menjadi cair.

Peserta pelatihan dipilih oleh aparat desa dengan kriteria, memiliki kebun atau dekat dengan hutan kemasyarakatan yang membudidayakan tanaman kayu putih. Pada kegiatan ini seluruh peserta adalah kepala rumah tangga yang diharapkan dapat memberikan keputusan untuk terlibat secara berkesinambungan pada kegiatan ini. 


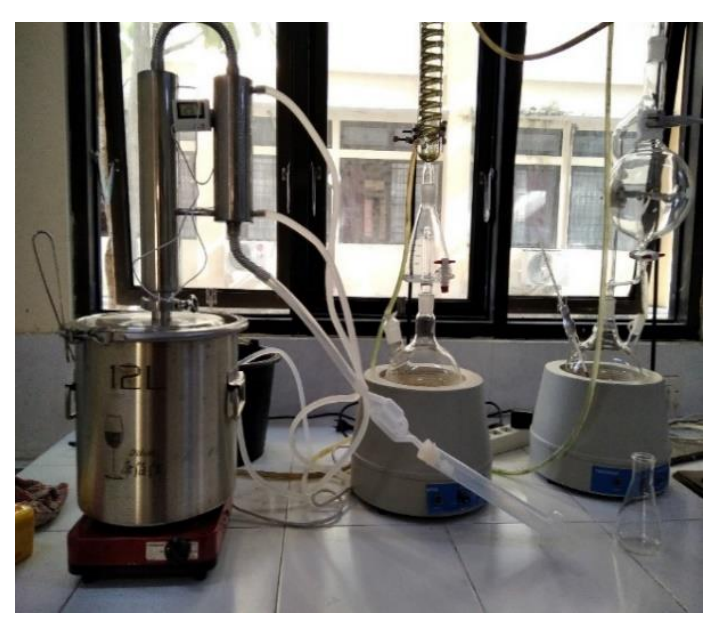

Gambar 1. Alat destilasi uap

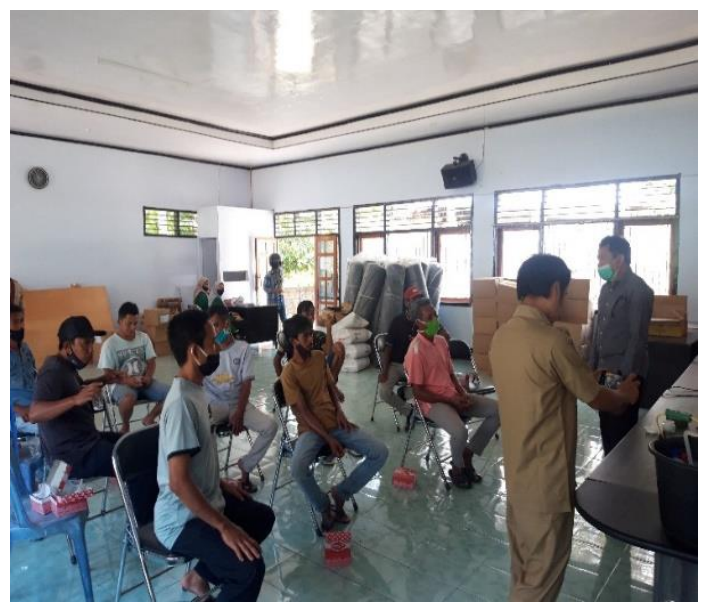

Gambar 2. Penyampaian materi penyuluhan minyak atsiri kayu putih

Penyampaian materi dilakukan dengan metode ceramah dan demonstrasi yang dilanjutkan dengan diskusi, sehingga menimbulkan interaksi antara peserta dengan narasumber. Adapun materi yang disampaikan selain yang telah diuraikan sebelumnya juga didiskusikan potensi bisnis dari tumbuhan kayu putih.

Pada proses pemisahan minyak kayu putih, metode yang dijelaskan dan didemontrasikan adalah distilasi uap dengan produk utama minyak atsiri dan campuran air dan minyak atsiri. Selain itu dihasilkan limbah daun yang kesemua ini dijadikan bahan campuran dalam pembuatan sabun, lotion, dan lulur.
Secara teknis, bagaimana pembuatan masing-masing produk akan dipublikasikan pada artikel yang lain. Produk-produk ini diharapkan dapat dijadikan produk khas desa Ganggelang yang bisa diintegrasikan dengan industry parawisata.

Kegiatan demonstrasi penyulingan minyak kayu putih dimulai dari bagaimana mengambil daun, proses pengeringanginan sebelum siap didistilasi. Pengesetan alat distilasi juga dijelaskan yang dilanjutkan dengan proses didistilasi. Pada akhirnya diberikan contoh produk utama dan limbah yang dihasilkan. Akhirnya, pada sesi kedua dijelaskan didiskusikan teknik pembuatan sabun, lotion dan lulur.

Pada kesempatan diskusi berkembang berbagai isu tidak saja berkaitan dengan isu teknis distilasi dan pembuatan produk tetapi juga menyangkut prosfek ekonomi dari pengembangan home industry pemanfaatan daun kayu putih ini. Diskusi berlangsung dengan terbuka, dimana masyarakat sering mengeluhkan adanya kegiatan serupa dari berbagai pihak namun kegiatan nyata di lapangan tidak berlanjut. Dari diskusi terungkap bahwa sebagian besar kegiatan penyuluhan tidak berlanjut, dikarenakan berbagai hal, diantaranya, 1) tidak adanya komitmen bersama untuk menindaklanjuti hasil penyuluhan, baik itu pihak penyuluh atau pihak desa, 2) Kegiatan penyuluhan tidak bersifat multiyear untuk memastikan kegiatan penyuluhan berlanjut sampai terbentuknya unit pelaksana, terutama yg bersifat bisnis, 3) Peserta penyuluhan berasal dari kalangan orang tua yang kurang dan bahkan tidak memiliki semangat bisnis yang kuat, walaupun pada saat penyuluhan mereka terlihat sangat antusias. 


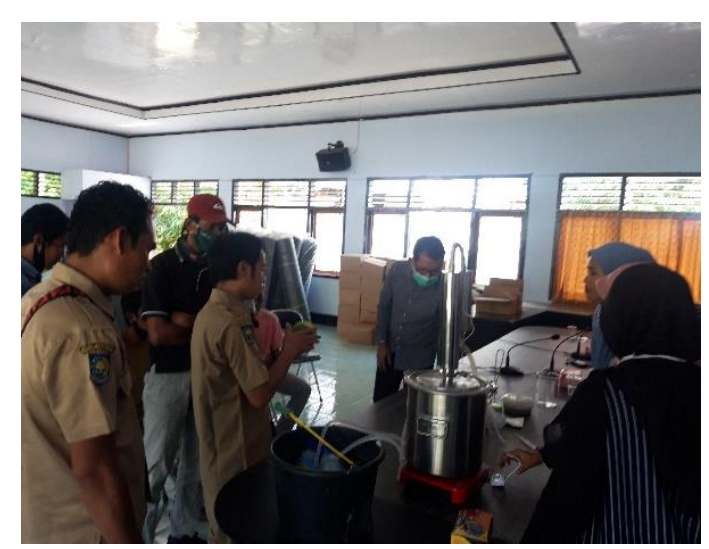

Gambar 3. Suasana demonstrasi penyulingan minyak atsiri kayu putih

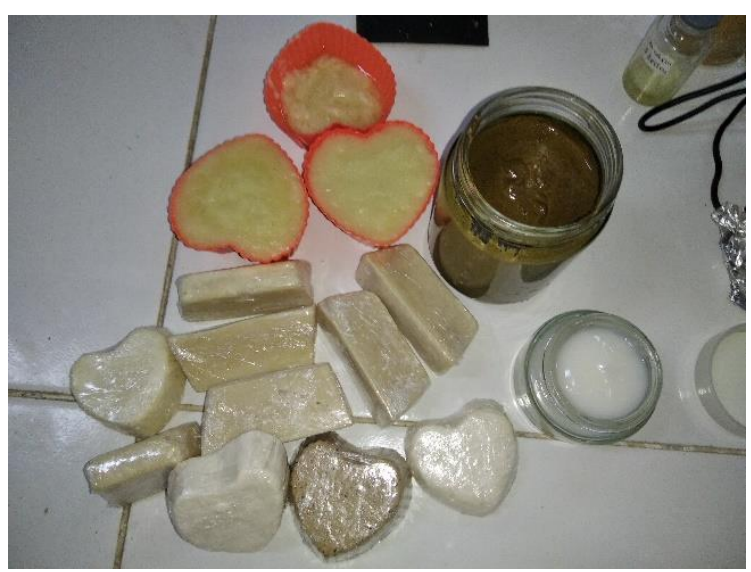

(A)

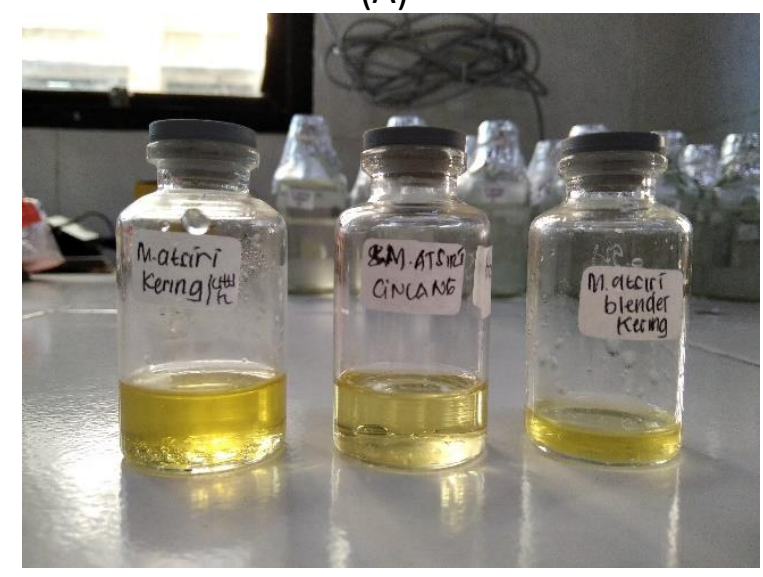

(B)

Gambar 4. Hasil penyulingan minyak atsiri kayu putih (A) dan produk olahannya (B)

Evaluasi kegiatan telah dilakukan dan hasil evaluasi ditunjukkan pada Tabel 1. Dari tabel tersebut secara umum terlihat bahwa pelaksanaan pelatihan secara umum telah berjalan cukup efektif. Kesesuaian jadwal kegiatan, kehadiran dan keaktifan peserta sesuai dengan kriteria penilaian. Penguatan pendanaan kegiatan sangat perlu dilakukan untuk dapat mengintensifkan pelatihan dan untuk memulai kegiatan persiapan dan proses produksi dan pemasaran produk.

Berasarkan hasil diskusi selama pelatihan maka disepakati bahwa kegiatan ini harus dilanjutkan dengan mengusahaan sumber pendanaan yang memungkinkan tersedianya peralatan destilasi untuk skala industry rumah tangga dan tersedianya modal awal untuk memantapkan penguasaan keterampilan dan proses-proses produksi serta tahapan bisnis lainnya.

Tabel 4.1. Kondisi pelaksanaan pelatihan pengembangan home industry minyak atsiri

\begin{tabular}{lllc}
\hline \multicolumn{1}{c}{ Aspek } & \multicolumn{1}{c}{ Kriteria Pelatihan } & \multicolumn{1}{c}{ Hasil Evaluasi } & Taksir-an \\
\hline $\begin{array}{l}\text { Kesesuaian dengan } \\
\text { rencana }\end{array}$ & Sesuai dengan rencana & $\begin{array}{l}\text { Pelatiha telah sesuai } \\
\text { dengan rencana }\end{array}$ & Efektif \\
\hline Ketersediaan dana & Tersedia dana yang cukup & Dana masih swadaya & $\begin{array}{c}\text { Belum } \\
\text { efektif }\end{array}$ \\
\hline Kehadiran peserta & $\begin{array}{l}\text { Kehadiran Peserta lebih } \\
\text { dari 75\% }\end{array}$ & $\begin{array}{l}\text { Seluruh peserta } \\
\text { hadir }\end{array}$ & Efektif \\
\hline Keaktifan peserta & Peran aktif dalam kegiatan & Seluruh peserta aktif & Efektif \\
\hline
\end{tabular}




\begin{tabular}{lll}
\hline Nara-sumber $\quad$ Kompetensi Narasumber & $\begin{array}{l}\text { Narasumber memapar- } \\
\text { kan sesuai dengan yang } \\
\text { dibutuhkan }\end{array}$ & Efektif \\
\hline
\end{tabular}

Selain itu, pelibatan generasi yang memiliki semangat bisnis harus dipadukan dengan peserta yang ada dalam kelompok. Bisnis memerlukan semangat dan ketekunan yang sangat tinggi dan kebutuhan ini diharapkan dapat ditemukan pada anak-anak muda yang berasal dari desa lokasi pengabdian masyarakat ini.

\section{KESIMPULAN}

Teknik yang digunakan untuk mendapatkan minyak atsiri daun kayu putih menggunakan destilasi uap yang menghasilkan produk utama minyak atisi kayu putih, campuran minyak atsiri dan air serta limbah daun. Ketiga bahan ini sekanjutnya dimanfaatkan untuk pembuatan sabun, lotion dan lulur. Upaya yang telah dilakukan untuk melatih dan membangun motivasi peserta adalah dengan memberikan pemaparan dan demonstrasi teknik penyulingan minyak atsiri daun kayu putih Pelatihan berlangsung cukup efektif dalam rangka mengenalkan berbagai produk yang berbasis pada pemanfaatan minyak atsiri daun kayu putih. Diskusi berlangsung sangat baik yang memberikan peluang besar untuk menindaklanjuti hasil penyuluhan. Sumber pendanaan sangat perlu dicari untuk mewujudkan terciptanya usaha skala rumah tangga ini. Pelibatan generasi muda yang memiliki semangat dan motivasi kuat untuk bisnis harus dilakukan.

\section{Ucapan Terima Kasih}

Tim pengabdian mengucapkan terima kasih Universitas Mataram yang telah memberikan dana dan desa mitra, Desa Genggelang, yang telah memfasillitasi tempat kegiatan dan pembentukan kelompok sehingga kegiatan ini dapat berlangsung.

\section{Daftar Pustaka}

Deaton, A. 2003. Measuring Poverty. Research Program Development Studies: Princeton University.

Kabupaten Lombok Utara dalam Angka 2019. BPS Kabupaten Lombok Utara.

Kecamatan Gangga dalam Angka 2019. BPS Kabupaten Lombok Utara.

Tanasale, M.L.P. 2012. Aplikasi Perlakuan Bahan Baku dan Penyulingan AirUap terhadap Rendemen dan Sifat Organoleptik Minyak Atsiri. Jurnal Ekologi dan Sains (Ekosains), 1 (1): 18.

Tirta, IG dan I Putu Agus Hendra Wibawa. 2017. Eksplorasi Tumbuhan yang Berpotensi sebagai Penghasil Minyak Atsiri di Lombok Timur-NTB. Jurnal Biologi Udayana Volume 21 (1): 12-16.

https://ppid.birohumasprotokol.ntbprov.g o.id/industrialisasi-minyak-atsiriberbasis-desa-lingkar-hutandikembangkan-di-ntb/, diakses pada 24 Februari 2020.

http://www.horsessentials.com/gb/conte $\mathrm{nt} / 20$ aromatherapy-distillation, diakses pada 27 Februari 2020. 